\title{
Transcriptional Level of Cumulus-Associated GJA1, PTX3, PRSS35, and SERPINE2 Genes with Oocytes and Embryonic Development in Water Buffalo
}

\section{Lalit Jeena ( $\nabla$ m.l.jeena@gmail.com )}

Maulana Azad Medical College https://orcid.org/0000-0001-6532-8814

D.K. Singh

Nanaji Deshmukh Veterinary Science University

Sandeep Rahangdale

Nanaji Deshmukh Veterinary Science University

Ajit Pratap Singh

Nanaji Deshmukh Veterinary Science University

B.C. Chandra Sarkhel

Nanaji Deshmukh Veterinary Science University

\section{Research Article}

Keywords: Cumulus-oocyte complexes (COC's), in-vitro fertilization, embryo, gene expression.

Posted Date: January 31st, 2022

DOI: https://doi.org/10.21203/rs.3.rs-1289084/v1

License: (9) This work is licensed under a Creative Commons Attribution 4.0 International License.

Read Full License 


\section{Abstract}

\section{Background:}

In the present study, the potential of different groups of cumulus-oocyte complexes (COC's) for in-vitro maturation (IVM) and embryonic development was assessed in two groups of COC's of water buffalo. Further, the association of the expression pattern of cumulus-associated GJA1, PTX3, PRSS35, and SERPINE2 genes and their effects on embryonic development was analyzed. Slaughterhouse-derived buffalo oocytes were graded into group $A$ and $B$ based on surrounding cumulus rings. Out of 1000 ovaries, an equal number of 410 COC's were taken in both the A and B groups. Invitro maturation (IVM) was carried out using Slaughterhouse-derived buffalo epididymis. A remarkable degree of cumulus expansion was noticed in group A (92.68\%) as compared to group B (81.25\%) oocytes. On IVF and embryo culture, group A COC's produced a significantly higher rate of cleavage and blastocyst $(92.682 \pm 0.7179 \%$ and $42.682 \pm 0.9683 \%)$ as compared to group B COC's $(85.365 \pm 0.7608 \%$ and $31.707 \pm 0.9688 \%)$, respectively. The transcriptional analysis of cumulus-associated GJA1, PTX3, PRSS35, and SERPINE2 genes expression by quantitative Real Time-PCR (qRT-PCR) revealed a significantly higher expression in group A as compared to group B COC's.

Result: It was revealed that oocytes having good cumulus mass had a higher developmental potential. Based on differential gene expression of cumulus-associated genes, different quality of COC's, and the resultant embryos after IVF, it was concluded that these genes could be used as a marker for predicting the developmental competence of the oocytes.

Conclusion: It concluded from the study that morphologically good quality of COC's had a higher developmental competence. Also, the differential expressions of cumulus-associated genes in cumulus cells and embryos, we can conclude that these genes could be used as marker genes for predicting the developmental competence of buffalo's oocytes.

\section{Background}

In-vitro maturation (IVM), in-vitro fertilization (IVF), and gamete cryopreservation technologies provide a practical means for producing a large number of bovine embryos at a low cost for research and commercial settings [1-3]. Various factors have been affected the successful In-Vitro production of buffalo embryos including a low number of follicles on the ovaries, sperm mortality, in-vitro laboratory conditions. [4-5], a poor recovery rate of the oocytes [6-7], and poor in-vitro fertilization efficiency [8-10]. In early embryo development, defining oocyte quality remains one of the most difficult challenges. Follicular growth and maturation are prerequisites to oocyte fertilization and subsequent early embryo development [8]. Among all the events involved in this process, those taking place precisely at the preovulatory stage within the cumulus-oocyte-complexes (COC's) might offer new criteria for choosing embryos with the best development ability [11-13]. Previous studies emphasized the roles of cumulus mass in nurturing oocyte growth, gradual acquisition of oocyte developmental competence suggested 
that cumulus cells metabolize the bulk of glucose consumed by the COC's, supplying metabolic intermediates like pyruvate, mainly through glycolysis, to the oocyte and regulating the oocyte gene transcription [14-16].

In the livestock sector, in-vitro fertilization (IVF) technology can be a useful tool for fruitful output in mammalian species like cows, buffaloes, goats, and pigs. The good qualities of cumulus cells (CC's) are very important for successful in-vitro fertilization. Oocyte cumulus undoubtedly plays an important role in oocyte quality and maturation but the eject mechanism behind this is still unknown [17]. Therefore, an extensive study is required to analyze whether the developmental potential of the COC's is associated with the expression of different cumulus genes in terms of maturation, fertilization, and embryonic development. Works of literature show that genes such as GJA1, PRSS35, PTX3, and SERPINE2 play a crucial role in oocyte maturation, fertilization, and embryonic development [18-24]. However, literature elucidating these cumulus-associated gene expressions, their significance, and the effect of cumulus cell layer/mass toward the embryonic developmental process are scarce in livestock.

Cumulus-associated GJA1 gene is the major gap junction a1 protein or connexin43, essential for oocyte fertilization potential and embryo quality [18]. PRSS35 gene belongs to the trypsin class of serine proteases, which is essential for the tissue remodeling and functions of the ovary during folliculogenesis and ovulation [19]. The gene PTX3 (Pentraxin-related protein 3) is linked to extracellular matrix (ECM) hyaluronan and is a potentially reliable predictor of embryo developmental competence [20]. The SERPINE2 (serine proteases E2) gene is considered a potential pregnancy biomarker [21] and is extensively expressed in reproductive tissues [22-24].

Our aim was, therefore, to evaluate the effects of cumulus cell mass on oocyte competence in terms of oocytes maturation and post-fertilization developments along with the expression of GJA1, PTX3, PRSS35, and SERPINE2 genes in cumulus cells according to stages in oocyte maturation and embryonic developmental competence in slaughterhouse derived buffalo oocytes.

\section{Methods}

All the chemicals and media were purchased from Sigma-Aldrich Chemicals Company (St. Louis, Monsanto) and the disposable plastic wares were from Nunc (Roskilde, Denmark) unless otherwise mentioned.

\section{Oocyte Aspiration And Grading}

Under a total of 30 trials (Sample size calculated by using, $n=Z^{2 *} P(P-1) / D^{2}$ formula), buffalo ovaries were collected from the large animal abattoir aseptically in normal saline solution $\left(37^{\circ} \mathrm{C}, \mathrm{pH} 7.0\right)$, supplemented with gentamicin $(50 \mu \mathrm{g} / \mathrm{ml})$. The ovaries were trimmed and washed 3-4 times in Dulbecco's phosphate buffer saline (1X, DPBS). This was followed by a quick wash of 30-40 seconds with 70\% ethanol and finally rinsed with DPBS. Oocytes were aspirated from 6-8 $\mathrm{mm}$ ovarian follicles by follicular 
aspiration method in a pre-warm $\left(37^{\circ} \mathrm{C}\right)$ DPBS medium. The oocytes were washed 3-4 times in TCM-199 (washing media, Hyclone), supplemented with $7.5 \%$ (v/v) fetal bovine serum (FBS, Hyclone,) plus 50 $\mathrm{mg} / \mathrm{ml}$ gentamicin. Recovered oocytes were grouped into 4 categories $A, B, C$, and $D$ [25], following the morphology of cumulus mass and cytoplasmic appearance of oocytes. Group A oocytes had a 3-4 compact layer of cumulus mass with evenly granular homogenous cytoplasm, whereas group B oocytes had 2-3 layers of cumulus mass with evenly granular homogenous cytoplasm. The oocytes with complete or incomplete 1-2 layers of cumulus mass with irregular dark ooplasm, and no cumulus mass with irregular dark ooplasm, were categorized under the $C$ and $D$ group of oocytes, respectively (Fig. 1a). Only group A and B COC's were taken for the gene expression study. Further, for gene expression analysis, oocytes from both groups were divided into three subsequent stages viz., cumulus cells of immature COC's, cumulus cells of matured COC's and fertilized early embryos.

\section{In-vitro maturation (IVM)}

In-vitro maturation medium containing TCM-199 Supplemented with $10 \mu \mathrm{g} / \mathrm{ml}$ follicle-stimulating hormone (FSH), luteinizing hormone (LH), $1 \mu \mathrm{g} / \mathrm{ml}$ estradiol, 7.5 percent $(\mathrm{v} / \mathrm{v})$ fetal bovine serum (FBS), 50 $\mu \mathrm{g} / \mathrm{ml}$ gentamicin, and $0.8 \mathrm{mM} / \mathrm{ml}$ sodium pyruvate. It was used for in-vitro maturation of oocytes in groups of 30 oocytes per droplet. The droplets were overlaid with sterile pre-equilibrated mineral oil. The maturation process was carried out under a humidified atmosphere (99\%) for 24 hours in a $\mathrm{CO}_{2}$ incubator having a $5 \% \mathrm{CO}_{2}$ level at $37^{\circ} \mathrm{C}$. The cumulus expansion and presence of the first polar body were observed under the inverted zoom microscope (Nikon, 100X), to assess the in vitro maturation of oocytes.

\section{Sperm preparation for in-vitro fertilization (IVF) and embryo culture}

Under 30 experimental trials, sperms were collected from abattoir-derived epididymis and processed under sterile conditions as described earlier for ovaries. Sperms were harvested from tubules of epididymis with a fine and gentle incision with a sterile surgical blade and collected in a sterile tube containing $10 \mathrm{ml}$ of Bracket and Oliphant (BO) media, supplemented with $1 \mathrm{mM}$ caffeine sodium benzoate. The sperm concentration, morphology, and gross motility were observed under the inverted microscope (Nikon, 100X). For in-vitro fertilization, the sperms were prepared and capacitated for matured oocytes as described by Jeena et a/ 2018 [26]. In short, exudate sperms suspension with BO media was centrifuged at $168 \mathrm{G}$ for $10 \mathrm{~min}$ and the supernatant was discarded. This step was repeated twice. The pellet was resuspended in $5 \mathrm{ml}$ of BO fertilization media fortified with $1 \%$ BSA plus $50 \mathrm{mg} / \mathrm{ml}$ heparin and centrifuged at $168 \mathrm{G}$ for $5 \mathrm{~min}$. The harvested pellet was re-suspended in $1 \mathrm{ml} \mathrm{BO}$ fertilization media and centrifuged at $168 \mathrm{G}$ for $1 \mathrm{~min}$. The pellet was loosened with a fine bore pasture pipette and kept inside the $\mathrm{CO}_{2}$ incubator for $30 \mathrm{~min}$ for capacitation and to allow good quality sperms to swim up. At the same time 30 matured oocytes from both groups $A$ and $B$ were transferred into a pre-equilibrated $\left(38.5^{\circ} \mathrm{C}\right) 50 \mu \mathrm{l}$ BO fertilization droplet overlaid with mineral oil. After 30 min capacitated sperms with a final concentration of $10^{6}$ were taken from the top layer of sperm suspension and co-incubated with oocytes at 5 percent $\mathrm{CO}_{2}$ at $38.5^{\circ} \mathrm{C}$ temperature under a humidified atmosphere for $18 \mathrm{~h} \mathrm{(Fig.} 1 \mathrm{~b}$ ). After $18 \mathrm{~h}$ of co- 
incubation, oocytes were denuded with 1 percent of hyaluronidase. The presumptive zygotes (Fig. 1c and Fig. 1d) were cultured in RVCL media (Research Vitro Cleave Medium, COOK, Australia). Each group of embryos were assessed for their embryonic developmental stages as cleavage (Fig. 1e), 4 cells (Fig. 1f), compact morula (Fig. 1g), and blastocyst development (Fig. 1h).

\section{Primer designing}

The Primers for $\beta$-actin, PTX3, PRSS35, and SERPINE2 were designed by using online software PRIMER EXPRESS 3.0. The GJA1 gene primer was taken as a reference primer. Primer sequence specificity was checked by an online available database from BLAST, NCBI (Tab. 1).

Table 1

Details of qRT-PCR (quantitative Real Time-PCR) primers

\begin{tabular}{|c|c|c|c|}
\hline S. No. & Gene name & Primer Sequence $\left(5^{\prime}-3^{\prime}\right)$ & Amplicon size \\
\hline 1. & $\beta-\operatorname{actin}(\mathrm{R})$ & CACCCAGCACAATGAAGA & \multirow[t]{2}{*}{$118 b p$} \\
\hline 1 & $\beta-\operatorname{actin}(\mathrm{F})$ & TGCTTGCTGATCCACATC & \\
\hline \multirow[t]{2}{*}{3.} & SERPINE2 (F) & AAGGGTTTGTGGAGATCACG & \multirow[t]{2}{*}{$170 \mathrm{bp}$} \\
\hline & SERPINE2 (R) & TAGGGCAGCTCGATGAAGTT & \\
\hline \multirow[t]{2}{*}{5.} & PRSS35(F) & CGACTACATCAAAGGCAGCA & \multirow[t]{2}{*}{$179 b p$} \\
\hline & PRSS35 (R) & АТСССТТТСТССТССТТССА & \\
\hline \multirow[t]{2}{*}{7.} & PTX3 (F) & CCATGCGTTCCAAGAAGATT & \multirow[t]{2}{*}{$217 b p$} \\
\hline & PTX3 (R) & GCGACCAGTCTGTTTTCCTC & \\
\hline \multirow[t]{2}{*}{9.} & GJA1 (F) & CCTGCCGCAATTACAACAAACAAG & \multirow[t]{2}{*}{$425 b^{[25]}$} \\
\hline & GJA1 (R) & АTСССТААСАСССССАATGAACCA & \\
\hline
\end{tabular}

\section{Gene expression level of cumulus-associated GJA1, PTX3, PRSS35, and SERPINE2 genes}

Cumulus-oocyte complexes (COC's) were denuded in 0.1 percent hyaluronidase for 10 min with a gentle vortex to remove the cumulus cells. The total RNA was extracted by the Trizol method from cumulus cells of both groups (A and B), and also from their subsequent stages of immature cumulus cells of COC's, matured COC's, and fertilized early embryos. A total of 30 COC's from both groups were taken for RNA extraction. cDNA was prepared by using the first-strand cDNA synthesis kit (Fermentas, K1622) from an equal amount of total RNA. 
qRT-PCR was performed with a total volume of $20 \mu$ l containing CDNA $(1 \mu \mathrm{l}), 1$ pico- mole of reverse and forward primer (Table 1), and 10 $\mu \mathrm{l}$ of 2X SYBER green master mix (Applied Biosciences). All reactions were performed in triplicate. The relative quantification of mRNA of each gene was evaluated by qRT-PCR (Applied Biosystems, 7300) using SYBR green chemistry. The relative gene expression analysis of GJA1, PTX3, PRSS35, and SERPINE2 genes was analyzed by using Livak and Schmittgen [27] formulation i.e., comparative $2 \varangle \Delta \Delta \mathrm{Ct}$ method. The housekeeping gene $\beta$-actin was used as an endogenous loading control to normalize the relative gene expression. Immature COC's of group A oocyte were taken as a referral control (1.0) for the expression analysis of cumulus-associated GJA1, PTX3, PRSS35, and SERPINE2 genes in both the groups. The purity of amplified products was checked by Ethidium Bromide $(E t B r, 0.5 \mu \mathrm{g} / \mathrm{ml})$ stained with 1.8 percent agarose gel electrophoreses.

\section{Statistical analysis}

The percent data of embryonic development were transformed by arcsine transformation $\left(\log _{N}\right)$ and subjected to analysis of variance by Hierarchical analysis of variance design, and the mean differences were compared by Duncan's Multiple Range Test $(P<0.05)$.

\section{Results}

\section{In-vitro maturation (IVM) of abattoir-derived buffalo oocytes}

Under 30 experimental trials, a total of 2070 COC's were retrieved from 1000 slaughterhouse-derived ovaries, out of which 550 were from group A, 800 from group $B$ (Table 2), and the rest of 720 were from group C and D. Only good quality COC's of group A and B were taken for in-vitro maturation and in in-vitro fertilization. The analysis of variance of the data on embryonic development (Table 3) revealed a highly significant $(P<0.01)$ between-group difference $(A$ and $B)$ for all the embryonic stages. However, there was no significant difference $(P>0.01)$ between the day of the experiment (bull effect), indicating that epididymal semen collected on a different day did not significantly affect embryonic development. Further, the embryonic development stages within the group differed significantly, shown in Table 3.

It was observed that the in-vitro maturation rate of group A was substantially higher as compared to group B oocytes, in terms of first polar body extrusion (Table 2). The cleavage ( 2 cells), 8 cells, morula and blastocyst development rate (Table 4$)$ in group $B(85.365 \pm 0.7608,65.853 \pm 0.7608,51.219 \pm 0.9575$ and $31.707 \pm 0.9688 \%)$ COC's were found significantly lower $(P \leq 0.05)$ compared to group $A$ $(92.682 \pm 0.7179,78.804 \pm 0.6878,59.756 \pm 0.9466$ and $42.682 \pm 0.9683 \%)$ in respect of all the embryonic development stages. 
Table 2

In-vitro maturation of group A and B of oocytes.

\section{Ovaries collected from buffalo slaughterhouse}

1000

\section{Oocytes aspirated \\ Grading of oocytes taken for study}

Group A

Group B
No. of oocytes set for IVM
Oocytes showing polar body $550(26.57 \%) \quad 508(92.36 \%)$

\section{(2.07 \\ oocytes ovary) \\ 2070}

Values within parentheses indicate mean \pm SE\%

\section{Table 3}

Analysis of variance for embryonic development.

\begin{tabular}{|lll|}
\hline Source of variation & Degree of freedom & Mean Square value \\
\hline Between Group & 1 & $0.535^{\star \star}$ \\
\hline Between the day of experiment (bull effect) & 28 & $0.401^{\mathrm{NS}}$ \\
\hline Between EDS within group & 3 & $23.812^{\star *}$ \\
\hline Error & 101 & 0.003 \\
\hline EDS-Embryonic development stage; ${ }^{* *}$ Significant $(\mathrm{P}<0.01)$, NS- Non-Significant. \\
\hline
\end{tabular}

Table 4

Mean embryonic development percentage in group A and B in-vitro fertilized oocytes.

\begin{tabular}{|lllll|}
\hline $\begin{array}{l}\text { No. of oocytes in } \\
\text { each group }\end{array}$ & \multicolumn{4}{l}{ Embryonic development stages (Mean \pm SE) } \\
\cline { 2 - 5 } & 2-4 cells (\%) & $\mathbf{8 - 1 6}$ cells & Morula (\%) & Blastocyst (\%) \\
\hline $\begin{array}{l}\text { Group A - 410 } \\
\text { fertilized oocytes }\end{array}$ & 380 & 320 & 245 & 175 \\
& $(92.682 \pm 0.7179)^{\mathrm{a}}$ & $(78.804 \pm 0.6878)^{\mathrm{a}}$ & $(59.756 \pm 0.9466)^{\mathrm{a}}$ & $(42.682 \pm 0.9683)^{\mathrm{a}}$ \\
\hline $\begin{array}{l}\text { Group B - 410 } \\
\text { fertilized oocytes }\end{array}$ & 350 & 270 & 220 & 130 \\
\hline & $(85.365 \pm 0.7608)^{\mathrm{b}}$ & $(65.853 \pm 0.7608)^{\mathrm{b}}$ & $(51.219 \pm 0.9575)^{\mathrm{b}}$ & $(31.707 \pm 0.9688)^{\mathrm{b}}$ \\
\hline Value with different superscripts within column differs significantly $(\mathrm{P} \leq 0.05)$. & \\
\hline
\end{tabular}

Transcriptional level GJA1, PTX3, PRSS35, and SERPINE2 genes in group A and B oocytes

The immature COC's of group A oocytes were taken as a referral control (1.0) for the expression analysis of GJA1, PTX3, PRSS35, and SERPINE2 genes in both group A and B. Further, both the groups were divided into their three subsequent stages of cumulus cell of immature COC's, cumulus cells of matured COC's and fertilized early embryos.

Cumulus-associated GJA1 gene expression and oocyte integrity 
The relative expression of the GJA1 gene was found significantly $(P \leq 0.05)$ higher in cumulus cells of immature COC's (1.0) compared to matured cumulus cells of COC's (0.74) and in the fertilized early embryos (0.22) of group A. The expression pattern was also significantly lower in group B immature cumulus cells of COC's (0.82), matured cumulus cells of COC's (0.42), and the fertilized early embryos (0.20) compared to group A (Fig. 2a). The present study revealed that the GJA1 gene was strongly associated with immature cumulus cells of COC's, and the abundance of this gene was reduced significantly towards the progression of developmental stages till fertilization (shown in Fig. 2a-b).

Figure 2a Relative quantification of the GJA1 gene in cumulus cells of COC's and in-vitro fertilized group $A$ and group B oocytes. RC GA-IM - Referral Control of group A, cumulus cells of immature COC's. GB-IM Group B, cumulus cells immature COC's. GA-M - Group A, cumulus of matured COC's. GB-M - Group B, cumulus of matured COC's. GA-F - Group A, fertilized early embryos. GB-F - Group B, fertilized early embryos. b Transcriptional level of GJA1 gene. Lane 1 - Endogenous control $\beta$ actin. Lane $5=100 \mathrm{bp}$ ladder. Lane 2, 3, 4 - Cumulus cells of immature COC's, cumulus cells of Matured COC's and fertilized early embryos of group A. Lane 6, 7,8 - Cumulus cells of immature COC's, cumulus cells of matured COC's and fertilized early embryos of group B.

\section{Cumulus-expressed PRSS35 and PTX3 mRNA levels correlated with oocyte maturation}

It was observed that $P R S S 35$ and $P T X 3$ had significantly $(\mathrm{P} \leq 0.05)$ higher expression levels in matured cumulus cells of COC's of both group A (1.3 and 1.3) and group B (1.2 and 1.1). Whereas, the expression levels of $P R S S 35$ and $P T X 3$ were significantly lower $(\mathrm{P} \leq 0.05)$ in fertilized early embryos of both group $\mathrm{A}$ ( 0.33 and 0.52$)$ and $B(0.22$ and 0.24$)$. Similar results were observed in immature cumulus cells of COC's in group $A(1.0)$ and $B(0.91$ and 0.80$)$. The results showed that the relative transcripts of PRSS35 and PTX3 genes increased significantly in in-vitro matured stages, but were reduced markedly in fertilized early embryos irrespective of oocyte groups (Fig. 3a-b and 4a-b).

Figure 4a Relative quantification of the PTX3 gene in cumulus cells of COC's and in-vitro fertilized group $A$ and group B oocytes. RC GA-IM - Referral Control of group A, cumulus cells of immature COC's. GB-IM Group B, cumulus cells immature COC's. GA-M - Group A, cumulus of matured COC's. GB-M - Group B, cumulus of matured COC's. GA-F - Group A, fertilized early embryos. GB-F - Group B, fertilized early embryos. $\mathbf{b}$ Transcriptional level of PTX3 gene. Lane 1 - Endogenous control $\beta$ actin. Lane $5=100 \mathrm{bp}$ ladder. Lane 2, 3, 4 - Cumulus cells of immature COC's, cumulus cells of matured COC's and fertilized early embryos of group A. Lane 6, 7, 8 - Cumulus cells of immature COC's, cumulus cells of matured COC's and fertilized early embryos of group B.

\section{mRNA expression pattern of SERPINE2 gene in cumulus cells associated with fertilization and embryonic development:}

The results showed that the relative expression of the SERPINE2 gene was significantly higher $(\mathrm{P} \leq 0.05)$ in fertilized early embryos of both group $\mathrm{A}(1.6)$ and $\mathrm{B}$ (1.08). As shown in Fig. 5a, the SERPINE2 gene expression was significantly lower $(P \leq 0.05)$ in matured oocytes of both groups $A(0.59)$ and $B(0.46)$ 
along with immature group B (0.79) and group A (1.0) oocytes. The expression level of the SERPINE2 gene in embryos produced by in-vitro fertilization was significantly higher in fertilized early embryos than the cumulus cells of immature and matured COC's (Fig. 5a-b).

Figure 5a Relative quantification of the SERPINE2 gene in cumulus cells of COC's and in-vitro fertilized group $A$ and group $B$ oocytes. RC GA-IM - Referral Control of group A, cumulus cells of immature COC's. GB-IM - Group B, cumulus cells immature of COC's. GA-M - Group A, cumulus of matured COC's. GB-M Group B, cumulus of matured COC's. GA-F - Group A, fertilized early embryos. GB-F - Group B, fertilized early embryos. b Transcriptional level of SERPINE2 gene. Lane 1 - Endogenous control $\beta$ actin. Lane $5=$ 100bp ladder. Lane 2, 3, 4 - Cumulus cells of immature COC's, cumulus cells, of matured COC's and fertilized early embryos of group A. Lane 6, 7,8 - Cumulus cells of immature COC's, cumulus cells, of matured COC's and fertilized early embryos of group B.

The overall expression pattern of cumulus-associated GJA1, PRSS35, PTX3, and SERPINE2 genes at their subsequent developmental stages in both groups were analyzed collectively. The expressions of these genes were found significantly higher in group A compared to group B (Fig S1). The amplified products were confirmed by amplification plot, melting curve (Fig. 6), and agarose gel electrophoresis. The products were identified by their specific band size (GJA1-425bp, SERPINE2-170bp, PRSS35-179bp, and PTX3-217bp) as shown in Fig. 2b, 3b, 4b, and Fig. 5b.

\section{Discussion}

Cumulus cells (CC's) originating from undifferentiated granulosa cells (GC's) differentiate in mural granulosa cells (MGC's) and CC's during antrum formation in the follicle by the distribution of location. [5-6]. GJA1 is the major isoform of connexins between GCs (granulosa cells): MGCs-MGCs (mural granulosa cells) and MGCs-CCs (cumulus cells) [12]. Gap junctions transmit nutrients and small molecules such as ions, metabolites, amino acids, and intracellular signaling molecules from GCs to oocytes via CCs [18-19]. We observed the expression level of the GJA1gene in immature cumulus cells of COC's was significantly higher as compared to matured cumulus cells of COC's and fertilized oocytes of both groups (A \& B, Fig. 2a-b). A similar type of study was reported by Edry and workers, they found GJA7-mediated gap junctional communication regulates oocyte meiosis resumption, and lower levels of GJA1 in cumulus cells are beneficial for oocyte maturation [28]. While Feuerstein and Mishra reported contrasting results wherein relative expression of the GJA1gene was significantly lower in immature cumulus cells of COC's [29-30]. However, GJA7expression in cumulus cells surrounding the matured oocytes did not show any difference in developing embryos with good or poor morphology [29]. Hasegawa reported a significantly lower expression of GJA1 for embryos with good morphology [12]. Similarly, we revealed significantly lower expression of the GJA7gene was observed in fertilized oocytes and matured cumulus cells of COC's. 
PRSS35 belongs to the trypsin class of serine proteases, essential for follicular growth, ovulation, as well as for luteal formation and regression. PRSS35 gene expression was localized in theca cells of pre-antral follicles, the theca and granulosa cells of pre-ovulatory, ovulatory follicles, and developing corpus luteum $[15,19,31]$. Whereas, the PTX3 gene is localized in the cumulus matrix and plays a crucial role in cumulus expansion. Various cumulus proteins linked to extracellular matrix hyaluronan, are required for regulating cumulus integrity, which ensure cumulus expansion and oocyte maturation $[14-15,18,20$, 32-35]. A previous study reported PRSS35 and PTX3 mRNA levels are associated with oocyte interiority and fertilization potential [15].

Our data revealed that $P R S S 35$ and $P T X 3$ mRNA levels are associated with the oocyte maturation potential (Fig. 2). The higher expression of PRSS35 and PTX3 genes were observed in cumulus cells of COC's of matured oocytes of both groups (A \& B, Fig. 3a-b \& Fig. 4a-b). However, it was found significantly lower in cumulus cells of immature COC's and fertilized oocytes. Li et al [15] reported a relationship between PRSS35 expression and oocyte competence. While the expression of PTX3 has been reported to be significantly lower in cumulus cells from immature oocytes than in those from mature oocytes, which was found similar to our study. Similarly, Huang [32] demonstrated that the expression level of the PRSS35 gene plays an important role in oocyte nuclear maturation and gaining developmental competence. According to Miyakoshi the PRSS35 mRNA level increased the time of ovulation and remained elevated in the developing corpus luteum [36]. Although the scientific literature regarding the association of the PRSS35 and PTX3 genes with the oocyte and embryo developments is less in livestock. However, some studies have been reported in a few species like mouse and human oocytes and embryos.

Salustri and co-workers [34] reported the infertility of PTX3 null mice was associated with severe abnormalities of the cumulus ionophores and failure of in-vivo, but not in-vitro oocyte fertilization. Zhang [20] reported that the expression of the PTX3 gene in cumulus cells was indicative of oocyte and embryo quality. However, Diao and co-workers reported the PRSS35-null mice to have no defects in female fertility, suggesting that the gene is non-functional for murine fertility as well as in embryonic development. Also, he did not detect any compensatory up-regulation of other proteases reported in the uterus; but, the expression of other protease-related genes cannot be ruled out [31]. However, this remains unclear in the case of mammalians. We found the higher expression of PRSS35 and PTX3 genes in cumulus cells of matured COC's had a beneficial effect on oocyte competence and embryonic development.

SERPINE2 is a Serpin peptidase inhibitor (clade $\mathrm{E}$, member), which inhibits urokinase-type plasminogen activator (PLAU) and tissue-type plasminogen activator. These activators are associated with many types of reproductive processes, e.g., ovulation, embryonic development, and embryo implantation [22-24]. Hamel et al, reported the SERPINE2 mRNA levels in granulosa cells have been suggested to be a potential pregnancy biomarker [21].

Our data revealed that SERPINE2 mRNA levels are associated with oocyte fertilization potential. 
We found the expression of this gene was higher in fertilized oocytes of both groups (A \& B, Fig. 5a-b). However, the expression of the SERPINE2 gene was lower in cumulus cells of immature and matured COC's (Fig. 5a). Hamel and co-workers [13] also reported the SERPINE2 gene to be considered as a potential pregnancy biomarker and extensively expressed in reproductive tissues, the placenta, and the uterus [22, 31]. Sadeesh et al, reported the silencing of SERPINE2 expression using small interfering RNAs or blockage of SERPINE2 protein using a specific antibody did not affect oocyte maturation [2]. However, in a mouse, higher levels of SERPINE2 were demonstrated to impair cumulus expansion and oocyte maturation [19, 23, 37-38]. Li and coworkers reported the higher SERPINE2 expression levels were detected in cumulus cells of human immature oocytes than in those of mature oocytes [15]. According to our data, we found the higher expression of the SERPINE2 gene in fertilized oocytes suggested its significant role in fertilization and embryonic development.

The results of the present study showed that in all the cases, the expressions of cumulus-associated genes in group A were significantly up-regulated as compared to group B (supplementary Figure S1). The higher expression of these genes in group A COC's can be related to higher embryonic development compared to group B COC's showing down-regulation of all these genes compared to group A COC's. It might be concluded that the significantly higher expression of the GJA1 gene in cumulus cells of immature COC's along with PRSS35 and PTX3 genes in cumulus cells of matured COC's have a positive impact on oocyte developments. Similarly, a higher expression of the SERPINE2 gene in fertilized early embryos may have beneficial effects on oocyte fertilization and embryonic development in buffalo.

We found some contradictory results from a previous study which was in human embryos, where the study reported the GJA1 and SERPINE2 represent potential gene markers associated with oocyte maturation and PRSS35 may be correlated with oocyte fertilization potential [15, 39]. However, our study model was buffalo's embryos.

\section{Conclusion}

The selection of embryos with higher developmental potential has been one of the major factors in assisted reproductive technology (ART). Because, cumulus cells play a very important role in oocyte integrity and embryonic development. Although cumulus gene expression may represent a promising method compared with the currently used morphology-based method, more investigations are warranted. Thus, a prospective larger cohort study or the use of SET cumulus samples remains necessary to clarify the effectiveness. However, it was concluded from our study the morphologically good quality of COC's had a higher developmental potential in terms of maturation, fertilization, and embryonic development as compared to oocytes having poor quality of COC's (in both A \& B groups). Based on molecular analysis of differential expressions of cumulus-associated genes we found the GJA1 gene associated with immature oocyte integrity, PTX3 and PRSS35 represent gene markers potentially associated with oocyte maturation, and SEPINE2 may be correlated with oocyte fertilization potential. In summary, GJA1, PRSS35, PTX3, and SERPINE2 in cumulus cells of different quality of oocytes and their resultant embryos after IVF, we can 
conclude these genes could be used as biomarkers for predicting the developmental competence of buffalo's oocytes.

\section{Declarations}

Funding Info: No funding

Conflicts of interest/Competing interests: The authors declare that they have no Conflicts of interest.

Ethics approval: There was no need for ethical approval for this study. Slaughterhouse-derived ovaries and epididymis were used for in-vitro transcriptional analysis of cumulus-associated genes. No live animals were used.

Consent to Participate (Ethics): Not needed. In the in-vitro study, no live animals were used.

Consent to Publish (Ethics): Not needed. In the in-vitro study, no live animals were used.

Authors' contributions: Lalit Mohan Jeena wrote the manuscript. Bikash Chandra Sarkhel and Dharmendra Kumar helped in statistical analysis. Sandeep Rahangdale and Ajit Pratap Singh arranged the figures and references as per journal guidelines.

Availability of data and material: All data and materials for the study were provided by the Director of Animal Biotechnology Centre, NDVSU Jabalpur, M.P., India.

\section{References}

1. Hansen PJ (2006) Realizing the promise of IVF in cattle - an overview. Theriogenology 65:119-125. doi:

$10.1016 / \mathrm{j}$

2. Sadeesh EM (2015) In-vitro embryo production in buffalo: effects of culture system on preimplantation development and gene expression pattern. Curr Sci 109(3):603-607

3. Kumar D, Shukla MK, Jeena LM, Rahangdale S, Kumari D, Singh A, Sarkhel BC (2016) Assessment of in-vitro maturation of oocytes derived from slaughterhouse goat ovaries. Ruminant Science 5(1):1720. http://www.anandpub.com/archive-june-volume-2016-5-1-issue4

4. Huang RH, Zhou WH (2021) Granulosa cell biomarkers to predict oocyte and embryo quality in assisted reproductive technology. Reproductive and Developmental Medicine 5(1):30-77. .https://www.repdevmed.org/text.asp?2021/5/1/30/313684

5. Turathum B, Gao EM, Chian RC (2021) The Function of Cumulus Cells in Oocyte Growth and Maturation and in Subsequent Ovulation and Fertilization. Cells 2(9):2292. https://doi.org/ $10.3390 /$ cells 10092292

6. Nivet AL, Vigneault C, Blondin P, Sirard MA (2013) Changes in granulosa cells' gene expression associated with increased oocyte competence in bovine. Reproduction 145(6):555-565. doi: 


\subsection{0/REP130032}

7. Pengfei L, Jinzhu M, Wenzhong L, George WS, Jianbo Y, Lihua L (2016) Transcriptome analysis of bovine ovarian follicles at predeviation and onset of deviation stages of a follicular wave. International Journal of Genomics 3472748:1-9. doi.org/10. 1155/2016/3472748

8. Da Broi MG, Giorgi VSI, Wang F, Keefe DL, Albertini D, Navarro PA (2018) Influence of follicular fluid and cumulus cells on oocyte quality: clinical implications. Journal of Assisted Reproduction Genetics 35(5):735-751. doi.org/10.1007/s10815-018-1143-3

9. Ferre LB, Bogliotti Y, Chitwood JL, Fresno C, Ortega HH, Kjelland ME, Ross RJ (2016) Effect of spermatozoa motility hyperactivation factors and gamete co-incubation duration on in-vitro bovine embryo development using flow cytometrically sorted spermatozoa. Reproduction Fertility and Development 29(4):805-814. doi: 10.1071/RD15289

10. Uhde K, van Tol HTA, Stout TAE, Bernard AJR (2018) Metabolomic profiles of bovine cumulus cells and cumulus-oocyte-complex-conditioned medium during maturation in vitro. Sci Rep 8:9477. doi.org/10.1038/s41598-018-27829-9

11. Anderson RA, Sciorio R, Kinnell H, Bayne RA, Thong KJ, De-Sousa PA (2009) Cumulus gene expression as a predictor of human oocyte fertilization, embryo development and competence to establish a pregnancy. Reproduction 138(4):629-637. doi: 10.1530/REP-09-0144

12. Hasegawa J, Yanaihara A, Iwasaki S, Mitsukawa K, Negishi M, Okai T (2007) Reduction of connexin 43 in human cumulus cells yields good embryo competence during ICSI. J Assist Reprod Genet 24:463-466. doi: 10.1007/s10815-007-9155-4

13. Ortiz-Escribano N, Smits K, Piepers S, Vanden-Abbeel E, Woelders H, Van-Soom A (2016) Role of cumulus cells during vitrification and fertilization of mature bovineoocytes: Effects on survival, fertilization, and blastocyst development. Theriogenology 86(2):635-641. doi: $10.1016 / \mathrm{j}$

14. Downs SM (2001) A gap-junction-mediated signal, rather than an external paracrine factor, predominates during meiotic induction in isolated mouse oocytes. Zygote 9(1):71-82. doi: $10.1017 / \mathrm{s} 0967199401001071$

15. Li HS, Lin MH, Hwu MY, Lu HC, Yeh YL, Chen JY, Lee KKR (2015) Correlation of cumulus gene expression of GJA1, PRSS35, PTX3, and SERPINE2 with oocyte maturation, fertilization, and embryo development in human. Reproductive Biology and Endocrinology 13:93. doi: 10.1186/s12958-0150091-3

16. Xia GL, Kikuchi K, Noguchi J, Izaike Y (2000) Short time priming of pig cumulus-oocyte complexes with FSH and forskolin in the presence of hypoxanthine stimulates cumulus cells to secrete a meiosis-activating substance. Theriogenology 53(9):1807-1815. doi:10.1016/s0093691x(00)00316-2

17. Ebner T, Moser M, Sommergruber M, Tews G (2003) Selection based on morphological assessment of oocytes and embryos at different stages of pre-implantation development: a review. Hum Reprod Update 9(3):251-262. 10.1093/humupd/dmg 021 
18. Wang HX, Tong D, El-Gehani F, Tekpetey FR, Kidder GM (2008) Connexin expression and gap junctional coupling in human cumulus cells: contribution to embryo quality. Journal of Cellular and Molecular Medicine 13(5):972-84. doi:10.1111/j.1582-4934. 2008.00373.x

19. Wahlberg P, Nylander A, Ahlskog N, Liu K, Ny T (2008) Expression and localization of the serine proteases high-temperature requirement factor $\mathrm{A} 1$, serine protease 23 , and serine protease 35 in the mouse ovary. Endocrinology 149(10):5070-7. doi: 10.1210/en. 2007-1736

20. Zhang X, Jafari N, Barnes RB, Confino E, Milad M, Kazer RR (2005) Studies of gene expression in human cumulus cells indicate pentraxin 3 as a possible marker for oocyte quality. Fertil Steril 83(1):1169-1179. doi:10.1016/j.fertnstert.2004.11.030

21. Hamel M, Dufort I, Robert C, Gravel C, Leveille MC, Leader A (2008) Identification of differentially expressed markers in human follicular cells associated with competent oocytes. Molecular Human Reproduction 23(5):1118-27. dio: 10.1093/ humrep/ den048

22. Bedard J, Brule S, Price CA, Silversides DW, Lussier JG (2003) Serine protease inhibitor-E2 (SERPINE2) is differentially expressed in granulosa cells of dominant follicle in cattle. Molecular Reproduction Development 64(2):52-65. 10.1002/ mrd.10239

23. Chern SR, Li SH, Chiu CL, Chang HH, Chen CP, Chen EIT (2011) Spatiotemporal expression of SERPINE2 in the human placenta and its role in extravillous trophoblast migration and invasion. Reproduction Biology and Endocrinology 9:106. doi: 10.1186/1477-7827-9-106

24. Lee RK, Fan CC, Hwu YM, Lu CH, Lin MH (2011) SERPINE2, an inhibitor of plasminogen activators, is highly expressed in the human endometrium during the secretory phase. Reproduction Biology and Endocrinology 23:9-38. doi: 10.1186/1477-7827-9-38

25. Jeena LM, Kumar D, Rahangdale S, Singh AP, Sarkhel BC (2019) Effect of cumulus cells of cumulusoocyte complexes on in-vitro maturation, embryonic developmental and expression pattern of apoptotic genes after in-vitro fertilization in water buffalo (Bubalus bubalis). Aniaml Biotechnology 31(2):135-141. dio:10.1080/10495398.2018. 1554580

26. Jeena L, Kumar D, Rahangdale S, Singh A, Sarkhel BC (2018) In-vitro Development Competence of Buffalo Oocytes- Effect of Oocytes Quality on Maturation, Embryonic Developments and Apoptosis. International Journal of Livestock Research 8(11):73-80. doi: 10.5455/ijlr.20180512064048

27. Livak KJ, Schmittgen TD (2001) Analysis of relative gene expression data using real-time quantitative PCR and the $2 \rrbracket^{\Delta \Delta C t}$ method. Methods 25(4):402-408. doi. org/10.1006/meth.2001.1262

28. Edry I, Sela-Abramovich S, Dekel N (2006) Meiotic arrest of oocytes depends on cell-to-cell communication in the ovarian follicle. Mol Cell Endocrinol 252(1-2):102-106. doi: 10.1016/j.mce.2006.03.009

29. Feuerstein P, Cadoret V, Dalbies-Tran R, Guerif F, Bidault R, Royere D (2007) Gene expression in human cumulus cells: one approach to oocyte competence. Hum Reprod 22(12):3069-3077. doi: 10.1093/humrep/dem336 
30. Mishra A, Sharma GT, Kumar GS (2010) Expression profile of connexin 43 and poly A polymerase genes in buffalo (Bubalus bubalis) oocytes and developing embryos produced in-vitro. Journal of Applied Research 38(1):29-3. doi.org/10.1080/09712119. 2010.9707149

31. Diao H, Xiao S, Li R, Zhao F, Ye X (2013) Distinct spatiotemporal expression of serine proteases Prss 23 and Prss35 in periimplantation mouse uterus and dispensable function of Prss 35 in fertility. PLoS One 8(2):e56757. doi:10.1371/journal.pone.0056757

32. Huang X, Hao C, Shen X, Zhang Y, Liu X (2013) RUNX2, GPX3 and PTX3 gene expression profiling in cumulus cells are reflective oocyte/embryo competence and potentially reliable predictors of embryo developmental competence in PCOS patients. Reproductive Biology and Endocrinology 11:109. doi: 10.1186/1477-7827-11-109

33. Varani S, Elvin JA, Yan C, DeMayo J, DeMayo FJ, Horton HF, Byrne MC, Matzuk MM (2002) Knockout of pentraxin 3, a downstream target of growth differentiation factor-9, causes female subfertility. Mol Endocrinol 16(6):1154-1167. 10.1210/mend. 16.6.0859

34. Salustri A, Garlanda C, Hirsch E, De-Acetis M, Maccagno A, Bottazzi B, Doni A, Bastone A, Mantovani G, Beck-Peccoz P, Salvatori G, Mahoney DJ, Day AJ, Siracusa G, Romani L, Mantovani A (2004) PTX3 plays a key role in the organization of the cumulus oophorus extracellular matrix and in in-vivo fertilization. Development 131:1577-1586. doi: 10.1242/dev.01056

35. Scarchilli L, Camaioni A, Bottazzi B, Negri V, Doni A, Deban L, Bastone A, Salvatori GA, Mantovani GS, Salustri A (2007) PTX3 interacts with inter-alpha-trypsin inhibitor: implications for hyaluronan organization and cumulus oophorus expansion. Journal of Biology and Chemistry 282(41):3016130170. 10.1074/jbc.M7037 38200

36. Miyakoshi K, Murphy MJ, Yeoman RR, Mitra S, Dubay CJ, Hennebold JD (2006) The identification of novel ovarian proteases through the use of genomic and bioin-formatic methodologies. Biol Reprod 75(6):823-835. 10.1095/biolreprod.106.0522 90

37. Lu CH, Lee RK, Hwu YM, Lin MH, Yeh LY, Chen YJ, Lin SP, Li SH (2013) Involvement of the serine protease inhibitor, SERPINE2, and the urokinase plasminogen activator in cumulus expansion and oocyte maturation. PLoS ONE 30(8):e74602. doi: 10.1371/journal.pone.0074602

38. Devjak R, Fon Tacer K, Juvan P, Virant Klun I, Rozman D, Vrtacnik Bokal E (2012) Cumulus cells gene expression profiling in terms of oocyte maturity in controlled ovarian hyperstimulation using $\mathrm{GnRH}$ agonist or GnRH antagonist. PLoS ONE 7(10):e47106. doi: 10.1371/journal.pone.0047106

39. Lonergan P, Rizos D, Gutierrez-Adan A, Moreira PM, Pintado B, de la Fuente J, Boland MP (2003) Temporal divergence in the pattern of messenger RNA expression in bovine embryos cultured from the zygote to blastocyst stage in-vitro or in-vivo. Biology of Reproduction 69(4):1424-31. doi. org/10.1095/biolreprod.103.018168

\section{Figures}


Figure 1

Different developmental stages of buffalo embryo. a In-vitro maturation of different grades of the oocyte (100X). b Co-incubated of capacitated sperms with matured oocytes (100X). c Pro-nucleus after fertilization (2PN, indicated with a red arrow, 200X). $\mathbf{d}$ Secondary polar body (red arrow, 200X). e Cleavage (200X). f 4-Cells (200X). g Compact morula (200X). h Blastocyst (100X).
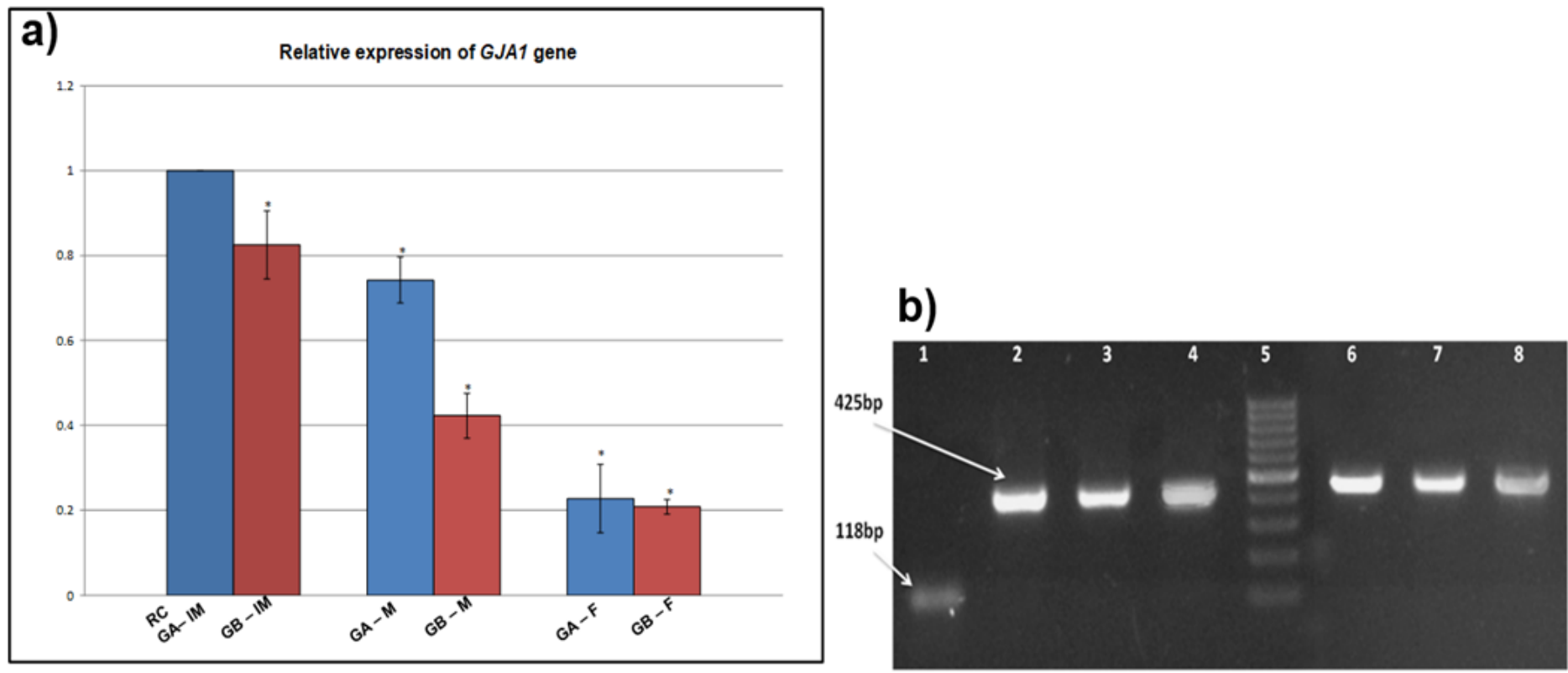

Statistically significant $(\mathrm{P} \leq 0.05)$ Bar depicts Mean $\pm \mathrm{SE}$

\section{Figure 2}

a Relative quantification of the GJA1 gene in cumulus cells of COC's and in-vitro fertilized group A and group B oocytes. RC GA-IM - Referral Control of group A, cumulus cells of immature COC's. GB-IM - Group B, cumulus cells immature COC's. GA-M - Group A, cumulus of matured COC's. GB-M - Group B, cumulus of matured COC's. GA-F - Group A, fertilized early embryos. GB-F - Group B, fertilized early embryos. b Transcriptional level of GJA1 gene. Lane 1 - Endogenous control $\beta$ actin. Lane $5=100 \mathrm{bp}$ ladder. Lane 2, 3,4 - Cumulus cells of immature COC's, cumulus cells of Matured COC's and fertilized early embryos of group A. Lane 6, 7, 8 - Cumulus cells of immature COC's, cumulus cells of matured COC's and fertilized early embryos of group $B$. 


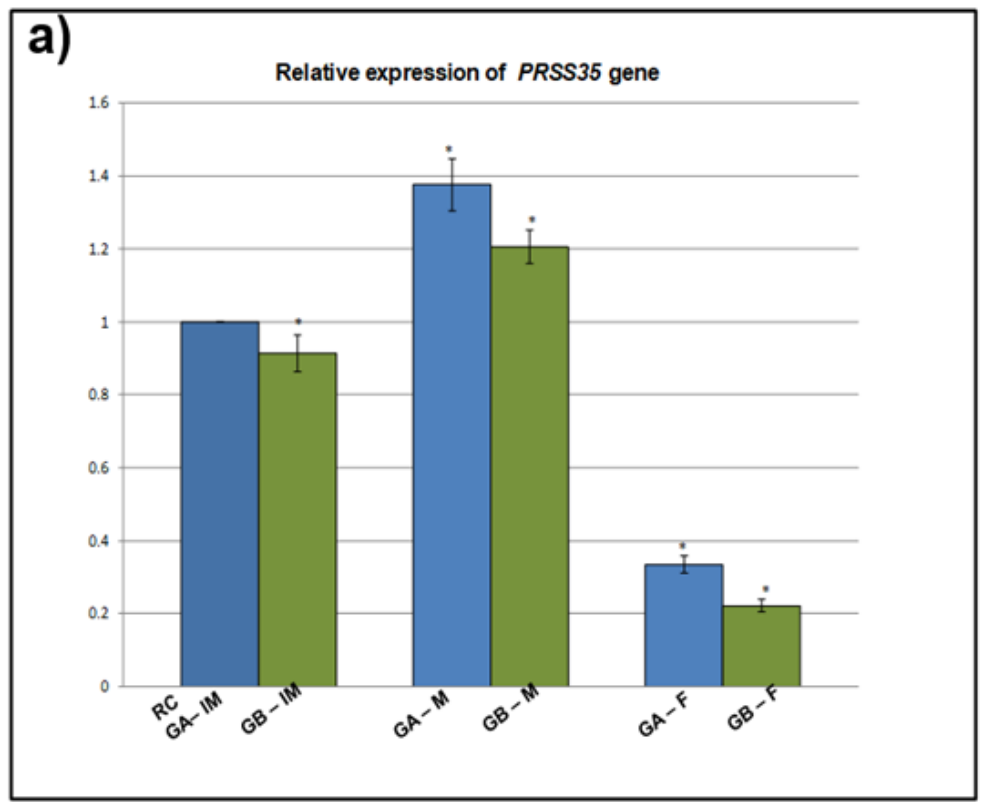

b)

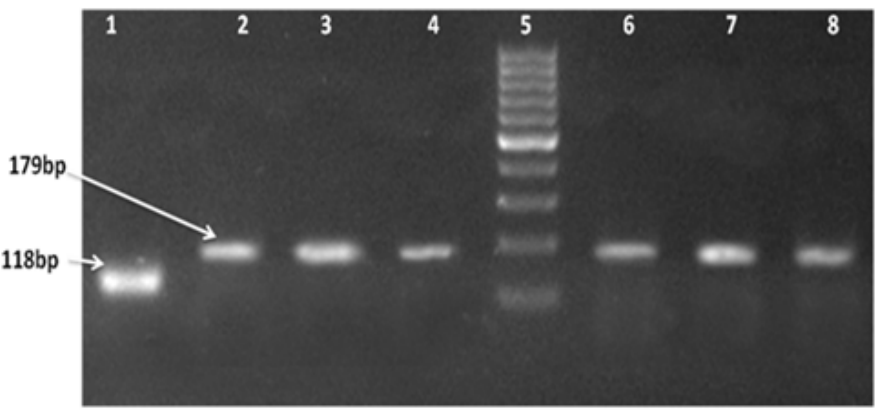

Statistically significant $(\mathrm{P} \leq 0.05)$ Bar depicts Mean $\pm \mathrm{SE}$

\section{Figure 3}

a Relative quantification of the PRSS35 gene cumulus cells of COC's and in-vitro fertilized group A and group B oocytes. RC GA-IM - Referral Control of group A, cumulus cells of immature COC's. GB-IM - Group B, cumulus cells immature COC's. GA-M - Group A, cumulus of matured COC's. GB-M - Group B, cumulus of matured COC's. GA-F - Group A, fertilized early embryos. GB-F - Group B, fertilized early embryos. b Transcriptional level of PRSS35 gene. Lane 1 - Endogenous control $\beta$ actin. Lane $5=100 b p$ ladder.Lane 2, 3, 4 - Cumulus cells of immature COC's, cumulus cells of matured COC's and fertilized early embryos of group A. Lane 6, 7, 8 - Cumulus cells of immature COC's, cumulus cells of matured COC's and fertilized early embryos of group $B$.
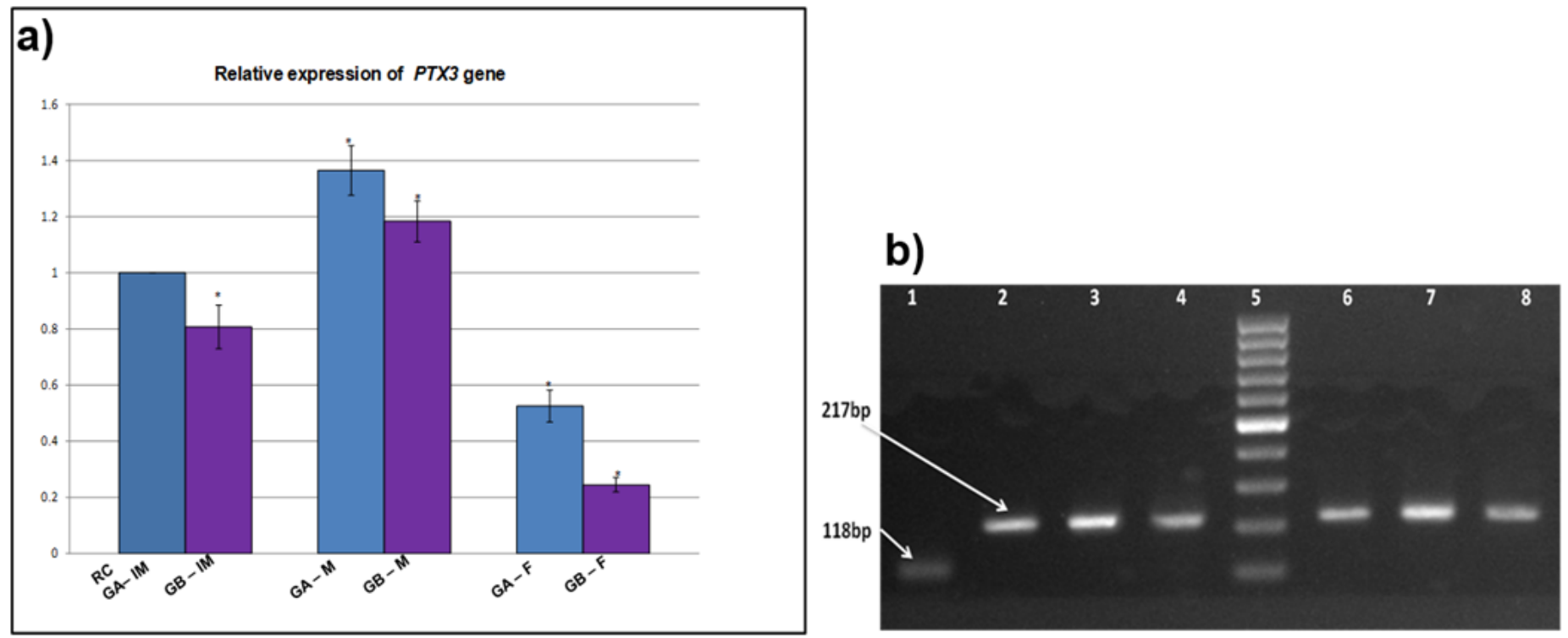

Statistically significant $(\mathrm{P} \leq 0.05)$ Bar depicts Mean $\pm \mathrm{SE}$ 


\section{Figure 4}

a Relative quantification of the PTX3 gene in cumulus cells of COC's and in-vitro fertilized group A and group B oocytes. RC GA-IM - Referral Control of group A, cumulus cells of immature COC's. GB-IM - Group B, cumulus cells immature COC's. GA-M - Group A, cumulus of matured COC's. GB-M - Group B, cumulus of matured COC's. GA-F - Group A, fertilized early embryos. GB-F - Group B, fertilized early embryos. b Transcriptional level of PTX3 gene. Lane 1 - Endogenous control $\beta$ actin. Lane $5=100 \mathrm{bp} \mathrm{ladder}$. Lane 2, 3,4 - Cumulus cells of immature COC's, cumulus cells of matured COC's and fertilized early embryos of group A. Lane 6, 7, 8 - Cumulus cells of immature COC's, cumulus cells of matured COC's and fertilized early embryos of group $B$.
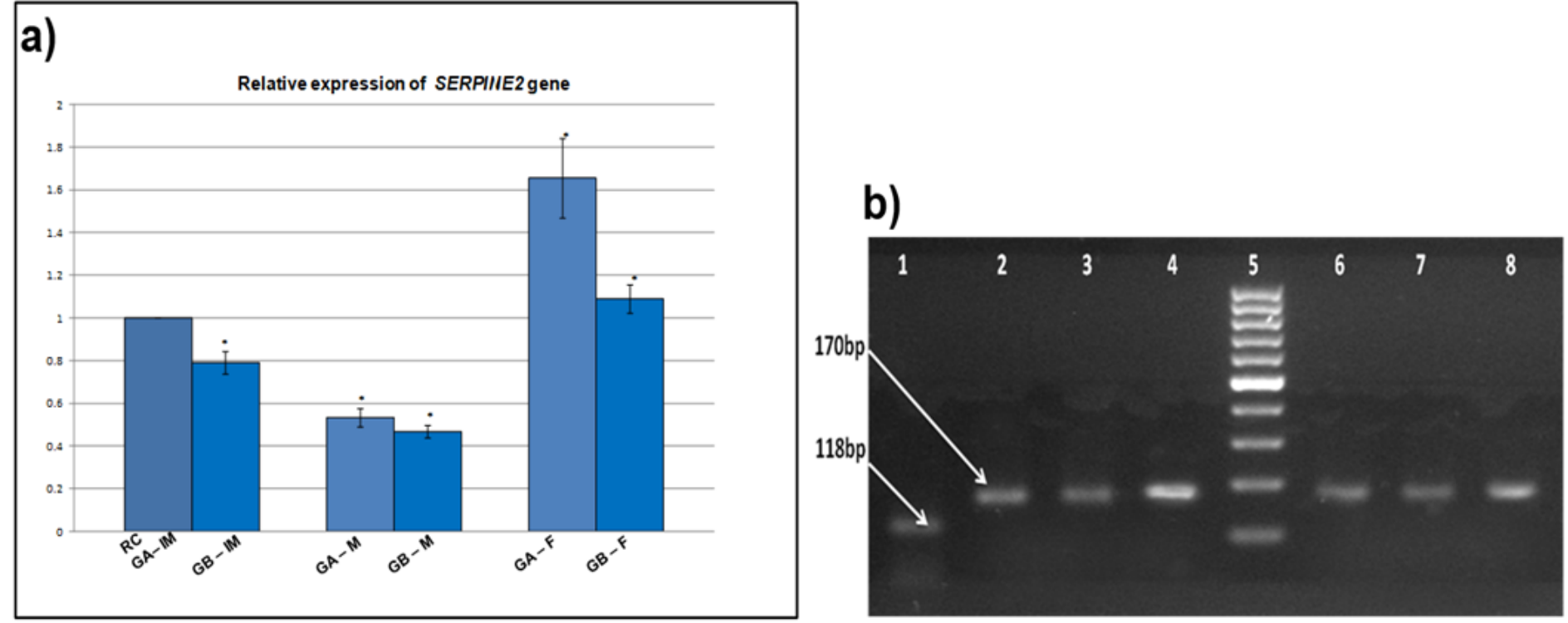

Statistically significant $(\mathrm{P} \leq 0.05)$ Bar depicts Mean $\pm \mathrm{SE}$

\section{Figure 5}

a Relative quantification of the SERPINE2 gene in cumulus cells of COC's and in-vitro fertilized group A and group B oocytes. RC GA-IM - Referral Control of group A, cumulus cells of immature COC's. GB-IM Group B, cumulus cells immature of COC's. GA-M - Group A, cumulus of matured COC's. GB-M - Group B, cumulus of matured COC's. GA-F - Group A, fertilized early embryos. GB-F - Group B, fertilized early embryos. b Transcriptional level of SERPINE2 gene. Lane 1 - Endogenous control $\beta$ actin. Lane $5=100 \mathrm{bp}$ ladder. Lane 2, 3, 4 - Cumulus cells of immature COC's, cumulus cells, of matured COC's and fertilized early embryos of group A. Lane 6, 7, 8 - Cumulus cells of immature COC's, cumulus cells, of matured COC's and fertilized early embryos of group B. 
Amplification plot and melting curve graph of GJA1, PRSS35, PTX3 and SERPINE2 genes.

\section{Supplementary Files}

This is a list of supplementary files associated with this preprint. Click to download.

- Figs1.png 